\title{
TOURISM SECTOR PERFORMANCE ON INDONESIA'S ECONOMIC GROWTH
}

\author{
Happy Febrina Hariyani \\ Department Economic Dvelopment, Faculty Economic and Business, \\ University of Muhammadiyah Malang \\ Email: happyfebrina@umm.ac.id
}

\begin{abstract}
Tourism is believed to be a booster for economic growth in developing countries. The tourism sector in Indonesia is one of the sectors that has the highest contribution in foreign exchange to the economy. Tourism activity in the form of export trade in services is the only sector that constantly make a positive contribution in the balance of trade in services in Indonesia. This study aims to analyze the influence of tourism consumption, tourism investment and government spending to economic growth. The results of this study indicate that, in the long run, those variables affect economic growth. While in the short run, they do not influence economic growth.
\end{abstract}

Key words: tourism, economic growth, investment, consumption, government expenditure

\section{INTRODUCTION}

The tourism sector is believed to provide a boost to the economic progress of developing countries. The development of the world tourism sector cannot be separated from trade liberalization as another form of globalization. The progress of this sector goes hand in hand with openness that occurs in various countries. The activity of trade in tourism services has contributed greatly to the state revenues, especially through foreign exchange earnings from foreign tourists through the expansion of job opportunities.

The World Tour and Tourism Council (2014) stated in its report that tourism has become the world's largest industry and the largest job creator. The worldwide tourism industry is estimated to contribute USD3.8 trillion to world GDP with 262 million jobs in 1997. In a decade, the figure grew to USD7.1 trillion with 383 million jobs. Tourism growth has almost doubled faster than world GDP (Prabowo, 2009).

The tourism sector is one of the main sources of foreign exchange in at least one of the three developing countries that have made the tourism sector a priority (Nath, 1998). Several studies have highlighted the potential of the tourism sector in encouraging growth, creating jobs and generating income for the government (Lea 1988; Sinclair 1998). Tourism is one of the most important activities in the world and is the sector most widely found in developing countries that have not been fully exploited. Before the terrorist attacks 
in September 2001, the world of tourism had grown at an average arrival rate of $7 \%$ per year and revenues of 12\% (WTO, 2003). In 2002, international tourism revenues reached USD 474 billion (WTO, 2003). It also estimates that tourism contributes USD3.7 trillion to the global economy. Tourism has made important contributions to socio-economic development in several countries that have chosen the tourism sector as a development strategy. The tourism sector is a very laborintensive sector and has a spill-over effect on other economic sectors.

The tourism sector in Indonesia is one of the sectors that contribute the highest foreign exchange in the Indonesian economy. Tourism activities in the form of export trade services are the only sector that consistently contributes positively to Indonesia's service trade balance (Lumaksono et al. 2012). The tourism sector is also the only service sector included in the ten export commodities with the largest contribution to the country's foreign exchange earnings. Other leading export commodities are oil and gas, palm oil, processed rubber, apparel, electrical equipment, textiles, paper and paper products, processed foods, and chemicals (Ministry of Tourism, 2012).
In 2010, the contribution of foreign exchange from the tourism sector reached USD 7603.45 million towards Indonesia's GDP and was ranked fifth as the sector with the largest income earner of foreign exchange. The total contribution of foreign exchange increased from year to year until in 2014. It reached USD 11,166.13 million and the ranking of the tourism sector rose to fourth position (Ministry of Tourism, 2014).

Traditionally, primary product exports have formed major export activities in developing countries such as Indonesia. Unfortunately, developing countries have made various efforts to promote the export of manufactured goods but this has often proved to be less successful. The main reason, among many other factors behind this lack of success can be summarized as lack of competitiveness, inability to catchup with the latest technology, and low quality. Currently, many developing countries that traditionally rely on income from primary product exports receive net currencies as a result of diversification into tourism, while the others try to generate additional income by increasing tourists flowing from abroad (Sinclair and Stabler, 1997). Foreign exchange earnings from goods exports are often hindered by imports of capital goods for investment purposes. 
Meanwhile, the foreign exchange potential of tourism and tourism-related activities creates a new pattern of production and trade.

The study conducted by EugenioMartin et al. (2004) regarding tourism and economic growth for Latin American countries show that the number of tourism arrivals, the previous year's GDP, investment from domestic income and state stability have a positive effect on economic growth. Government spending and the level of corruption negatively affect economic growth. In this study tourism variables were measured by the amount of investment and tourism arrivals in the previous year.

Studies related to the causal relationship between the acceptance of tourism and GDP have been carried out by Arslanturk et al (2010). The results of the study show a sensitive relationship to the countries analyzed, the sample period and the methodology used. Considering the sensitivity of the causal relationship, then a varied time estimation method is used to analyze Granger causality based on the Vector Error Correction Model (VECM). The findings of the study indicate that the results of the full sample in the VECM model have no Granger causality between series, whereas the findings from the varied time coefficient models indicate that GDP does not have predictive power for tourism revenue. However, tourism revenue has a positive-predictive relationship for the next GDP.

Meanwhile, Brida et al. (2008) stated that international tourism is an important foreign exchange earner and export for many years for low-income countries and developing countries. At present, many developing countries pay attention to economic policies to promote international tourism as a potential strategic factor for development and economic growth. The tourism-led economic growth hypothesis (TLGH) stated that tourism expansion leads to economic growth. The country's economic growth can be produced not only by increasing the amount of labor and capital in the economy, but also expanding exports.

Based on the discussion above, the main question examined in this study is whether the development in the tourism sector which include: consumption, investment and government spending affecting Indonesia's economic growth. To answer these problems, the purpose of the study is to analyze the effect of consumption, investment and government spending on the tourism sector on Indonesia's economic growth. 


\section{RESEARCH METHODS}

The type of data used in this study is secondary data in the form of annual data consisting of GDP, consumption in the tourism sector, investment in the tourism sector, and government expenditure in the tourism sector. The period used for this study is 1988 to 2014. Data is obtained from various sources including: World Tour and Tourism Council (WTTC), Ministry of Tourism, World Bank, Central Bureau of Statistics, and other relevant sources.

The analytical method used in this study is the Vector Autoregression (VAR) econometric method if the data is stationary and not cointegrated, then followed by the Vector Error Correction Model (VECM) method when the data is stationary and cointegrated. In this study, the Y variable is defined as GDP per capita (GDP), while the explanatory variables are domestic consumption in the tourism sector (CONS), capital investment in the tourism sector (INV), and government spending in the tourism sector (GOV).

Juanda and Junaidi (2012) stated that most of the time series econometric models are built on existing economic theories. Economic theory is the basis for developing relationships between variables in the model, but often economic theory has not been able to determine the exact specifications for the model because the existing economic phenomena are too complex and often the relationships between variables in a dynamic system cannot be explained by just the single static equation model. The Vector Autoregressive (VAR) model can be used to overcome this problem in time series data.

There are several forms of VAR models, one of which is the Vector Error Correction Model (VECM). VECM is the restrictive VAR used for variables that are non-stationary but have the potential to be cointegrated. In VECM, additional retention must be given because of the existence of non-stationary forms of data at the level, but cointegrated (Firdaus, 2011). In VAR and VECM analysis, it is necessary to do several tests such as stationary test, VAR stability test, optimal interval test, cointegration test, VECM, Impulse Response Function (IRF) technique, and Forecast Error Decomposition of Variance (FEVD).

The data stationarity test is carried out to fulfill the time series model requirements, where the data used is stationary. Data stationarity test is done using Augmented Dickey Fuller Test at level and first difference level. The data said to be stationary is when the $\mathrm{t}$-count results are smaller than t-critical MacKinnon at the 
$5 \%$ significance level. The optimal interval test is performed to eliminate the problem of autocorrelation.

In the VAR stability test if the modulus value is less than one, the VAR model is considered stable (Firdaus, 2011). VAR stability test is done so that the Impulse Response Function (IRF) and Forecast Error Variance Decomposition (FEVD) are valid.

Cointegration tests are carried out if data is not stationary at the level, but stationary at first difference. If there is no cointegration, VAR will be used first difference, whereas if there is cointegration then use the VECM model. In VECM, there is a gradual correction through short-term adjustments to the deviation of the long run equilibrium model (Juanda and Junaidi, 2012).

The Impulse Response Function (IRF) test is performed to see the response of an endogenous variable to shocks. Testing Forecast Error Variance Decomposition (FEVD) can explain the contribution of each variable to the shocks caused to the main endogenous variables observed (Paradise, 2011).

The VECM model used in this study is:

$$
\left[\begin{array}{c}
\Delta G D P \\
\Delta C O N S \\
\Delta I N V \\
\Delta G O V
\end{array}\right]=\left[\begin{array}{l}
\alpha_{10} \\
\alpha_{20} \\
\alpha_{30} \\
\alpha_{40}
\end{array}\right]+\left[\begin{array}{lll}
\alpha_{11} \alpha_{12} & \alpha_{13} & \alpha_{14} \\
\alpha_{21} \alpha_{22} & \alpha_{23} & \alpha_{24} \\
\alpha_{31} \alpha_{32} & \alpha_{33} & \alpha_{34} \\
\alpha_{41} \alpha_{42} & \alpha_{43} & \alpha_{44}
\end{array}\right]\left[\begin{array}{c}
\Delta G D P_{t-1} \\
\Delta C O N S_{t-1} \\
\Delta I N V_{t-1} \\
\Delta G O V_{t-1}
\end{array}\right]+\left[\begin{array}{l}
e_{1} \\
e_{2} \\
e_{3} \\
e_{4}
\end{array}\right]
$$

Description:

$G D P_{t}=$ Gross Domestic Product per capita (constant 2005, million US\$) CONSt $=$ Consumption in Tourism (million US\$)

$I N V_{t}=$ Investment in Tourism Sector (million US\$)

$G O V_{t}=$ Government Expenditure in Tourism (million US\$)

\section{RESULTS AND DISCUSSION}

\section{Tourism Sector in Indonesia}

Indonesia has a high tourist attraction because of the diversity of its natural and cultural wealth. There are thousands of attractions scattered on various islands in Indonesia, both in the form of commercial attractions, as well as historical heritage attractions. Based on Indonesian Infrastructure Statistics (2011), Indonesia has 3939 historical heritage attractions, consisting of 953 historic buildings, 203 historic bridges, 246 temples, 62 historic ports, 115 historic railway stations, and 2360 historic spiritual sites. Indonesia also has 3672 commercial attractions, consisting of 51 zoos, 558 water tourism, 188 agro tourism, 393 cultural tourism, 985 recreational parks, and 1497 natural tourism. Most of these attractions are managed by private or non-government parties. 
Indonesia is one of the ASEAN countries that has the potential of world tourism. Indonesia and other ASEAN countries began to focus on developing the tourism sector by forming a cooperation forum that resulted in a tourism agreement ASEAN Tourism Agreements (Djatmika, 2014). In addition, Indonesian tourism objects have a special attraction for foreign tourists.

The most famous Indonesian tourism in the world is Bali Island, where the island of Bali is famous as a natural tourism destination with beautiful beaches and traditional culture that is attractive to foreign tourists. Based on the results of a survey by Tripadvisor (2013), ten of Indonesia's most popular tourist destinations during 2012 were Bali
Waterboom in Kuta Bali, Prambanan Temple in D.I. Yogyakarta, Bali Safari \& Marine Park in Gianyar Bali, Borobudur Temple in Central Java, Tanah Lot Temple in Canggu Bali, Kecak Fire and Trance Dance Center in Ubud Bali, Mount Bromo East Java, Merapi Mountain Yogyakarta, Mount Rinjani Lombok, and Saung Angklung Udjo in Bandung.

Table 1 shows the input side components of the tourism sector that support Indonesia's economic growth. The development of each component showed an increase from year to year, except for the tourism expenditure component which had declined quite dramatically in 2013 from the previous year. However, this was offset by spending on tourism promotions whose numbers continued to increase until 2014.

Table 1. Consumption of Travelers, Investment and Government Expenditures, 2010 - 2013

\begin{tabular}{rrrrrr}
\hline & \multicolumn{5}{c}{ Input Component } \\
\cline { 2 - 6 } Year & $\begin{array}{c}\text { Consumption of } \\
\text { Foreign Tourist }\end{array}$ & $\begin{array}{c}\text { Consumption } \\
\text { of Domestic } \\
\text { Tourist }\end{array}$ & $\begin{array}{c}\text { Investment on } \\
\text { Tourism }\end{array}$ & $\begin{array}{c}\text { Expenditure } \\
\text { on Tourism }\end{array}$ & $\begin{array}{c}\text { Tourism } \\
\text { Promotion } \\
\text { Expenditures }\end{array}$ \\
\hline 2010 & 68.36 & 150.41 & 87.76 & 4.32 & 6.44 \\
2011 & 77.57 & 160.89 & 112.89 & 3.15 & 6.89 \\
2012 & 87.83 & 172.85 & 124.58 & 44.61 & 6.81 \\
2013 & 129.75 & 177.84 & 121.30 & 5.88 & 7.12
\end{tabular}

Source: National Tourism Satellite Accounts, Neparnas (2014) 
Tourism Sector Performance on Indonesia's Economic Growth

Stationarity testing in this study uses the Augmented Dickey Fuller (ADF) test. Tests are carried out at the level up to the first difference using the Schwarz Information Criterion assumption. The results of the data stationarity test are presented in Table 2 . The test results show that there are no stationary variables at the level, whereas in the first difference all variables are stationary. Then a cointegration test is performed, if there is cointegration, we can use the Vector Error Correction Model (VECM) model, but if there is no cointegration, VAR will be used first difference. Based on the cointegration test, variables are declared feasible to be estimated using VECM.

Table 2. Stationarity Test Results

\begin{tabular}{lclllll}
\hline & \multicolumn{3}{c}{ Level } & \multicolumn{2}{c}{ First difference } \\
Variable & $\begin{array}{c}\text { ADF } \\
\text { Statistics }\end{array}$ & $\begin{array}{l}\text { Mac Kinnon } \\
\text { Critical Value } \\
\text { of 5\% }\end{array}$ & Description & $\begin{array}{l}\text { ADF } \\
\text { Statistics }\end{array}$ & $\begin{array}{l}\text { Mac Kinnon } \\
\text { Critical Value } \\
\text { of 5\% }\end{array}$ & Description \\
\hline GDP & -0.60615 & -3.595026 & Not Stationary & -6.238782 & -3.612199 & Stationary \\
CONS & -1.91735 & -3.595026 & Not Stationary & -3.891484 & -3.603202 & Stationary \\
INV & -1.07428 & -3.595026 & Not Stationary & -3.643456 & -3.603202 & Stationary \\
GOV & -0.09633 & -3.595026 & Not Stationary & -4.158723 & -3.603202 & Stationary \\
\hline
\end{tabular}

The VECM estimation results in Table 3 show a combination of short-term to long-term relationships in the variable per capita GDP, consumption, investment, and government expenditure in the tourism sector. Testing these variables is done using the real level of $5 \%$. The VECM estimation result shows there is an error correction value of -0.086899 which is statistically significant at the $5 \%$ real level, which means that the imbalance (disequilibrium) will be corrected by -0.086899 to reach the long-term balance. Based on the VECM estimation results it is also known that in the short term there are no variables that influence economic growth (GDP per capita).

Meanwhile, the long-term estimation results show that all explanatory variables namely capital investment (INV), consumption (CONS) and government spending (GOV) in the tourism sector have a positive effect on GDP. That is, an increase in domestic consumption in the 
tourism sector will increase per capita GDP. The presence of domestic tourists is an important factor in influencing the development of Indonesian tourism. Increasing people's income and Indonesia's economic growth, as one of the factors increasing the number of tourist trips both inside and outside the country. According to the National Tourism Satellite Account
(2010), the number of domestic tourists at the end of 2009 was 218 million people or an increase of $5.6 \%$ in the last 5 years. The population of Indonesia who traveled to visit tourism objects and domestic tourist attraction in 2009 was not less than 300 trips, with total expenditure of $\mathrm{Rp} 105.9$ trillion.

Table 3. Estimating the Effects of Tourism Variables on Economic Growth

\begin{tabular}{ccc}
\hline & Short Run & \\
\hline Variable & Coefficient & T-Statistic \\
\hline CointEq1 & -0.086899 & -0.13830 \\
D(GDP(-1)) & 0.396310 & 0.78322 \\
D(GDP(-2)) & 0.275669 & 0.70501 \\
D(GOV(-1)) & 0.000148 & 0.28097 \\
D(GOV(-2)) & 0.000189 & 0.33223 \\
D(INV(-1)) & $-1.85 \mathrm{E}-05$ & -1.16126 \\
D(INV(-2)) & $-4.13 \mathrm{E}-06$ & -0.25592 \\
D(CONS(-1)) & $-5.43 \mathrm{E}-06$ & -0.73810 \\
D(CONS(-2)) & $-1.22 \mathrm{E}-06$ & -0.18292 \\
\hline GDP(-1) & Long Run & \\
\hline GOV(-1) & $1.000000^{*}$ & -5.60381 \\
INV(-1) & $0.000555^{*}$ & -6.98747 \\
CONS(-1) & $8.66 \mathrm{E}-06^{*}$ & -3.02634 \\
\hline
\end{tabular}

Description: *) significant variable at 5\%

Investment in the tourism sector also has a positive effect on economic growth. This means that an increase in investment in the tourism sector will affect the increase in economic growth (increase in GDP per capita). The positive influence of tourism sector investment on the economy indicates that capital investment can already be used to improve products and service quality in the tourism sector. According to Tambunan (2001), the existence of investment has an effect on increasing the amount of capital per worker which will then increase productivity per worker. In addition, the effect of investment on the economic growth of a region can occur when the 
investment climate is conducive. These climate conditions are related to good public services, pro-business government regulations, and legal certainty (Nuryadin and Sodik, 2005).

Hermawan (2009) also stated that investment in the tourism sector encourages economic growth. Investment in the tourism sector such as infrastructure development in the form of roads to tourist sites, ports and airports can increase the number of domestic and foreign tourist visits to tourist sites. This will increase revenue which will lead to an increase in Indonesia's economic growth. In addition, investment in the creation of safe services will also be very beneficial for the tourism industry, where tourist safety is a major factor if they visit a tourist attraction.

Government spending in the tourism sector also has a positive influence on GDP per capita, which is a reflection of economic growth. This condition is also supported by the theory of economic growth from the expenditure approach which states that government spending has a positive effect on the level of the economy. Government spending issued for productive sectors of society, especially in the tourism sector will increase people's income. This is related to the income received by the people who work on development projects that are funded by government spending. In addition, based on the research of EugenioMartin et al (2004) the total expenditure of the government will increase a country's economic growth, when these expenditures are used to spend on goods supporting people's production activities.

\section{Response of Economic Growth to Shocks that Occur in Each Variable (IRF)}

The Impulse Response Function (IRF) analysis will explain the economic growth response if there is a shock to other variables, namely consumption, investment, and government spending in the tourism sector. This study examined the effect of shock for 10 periods. The results in Figure 1 show that the shocks of one standard deviation in the consumption variable of the tourism sector were negatively responded to in the second year by $8.65 \%$ and began to stabilize at 7 to $37.09 \%$. The investment shock in the tourism sector by one standard deviation had a negative impact on economic growth in the second year of $16.11 \%$, and began to stabilize in the 5 th year by $30,006 \%$. \%. The shock of one standard deviation in the variable government expenditure in the tourism sector was responded positively in the second year by $5.313 \%$ and began to stabilize in the $6^{\text {th }}$ year by 48,16 

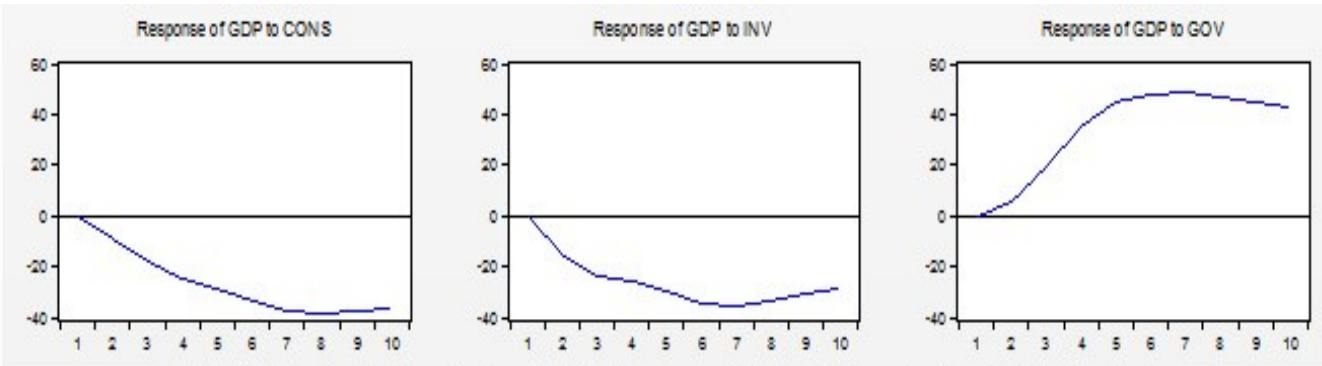

Figure 1. The Effects of Consumption, Investment, and Government Spending in The Tourism Sector on Economic Growth

Analysis of Forecasting Error Variance Decomposition (FEVD)

Analysis of Forecast Error Variance Decomposition (FEVD) aims to predict the contribution of the percentage variance of each variable due to changes in certain variables in the VAR system. FEVD analysis is used to describe the relative importance of each variable in the VAR system because of the shock (Juanda and Junaidi, 2012). The results in Figure 2 show that in the first year, economic growth fluctuations (GDP) is affected by the growth shocks themselves by $100 \%$. The influence of other variables began to appear from the second year. In the second year, GDP fluctuations were still dominated by GDP itself at $94.47 \%$, then influenced by CONS at $1.14 \%$, INV at $3.95 \%$, and GOV at $0.43 \%$. In the 10 th year there was a decrease in the effect of GDP on the diversity of GDP itself, Figure 2 shows that the effect of GDP is $38.20 \%$. In the 10th year, there was an increase in the influence of the CONS amount to $17.34 \%$, INV of $15.62 \%$, and influenced by GOV by $8.82 \%$.

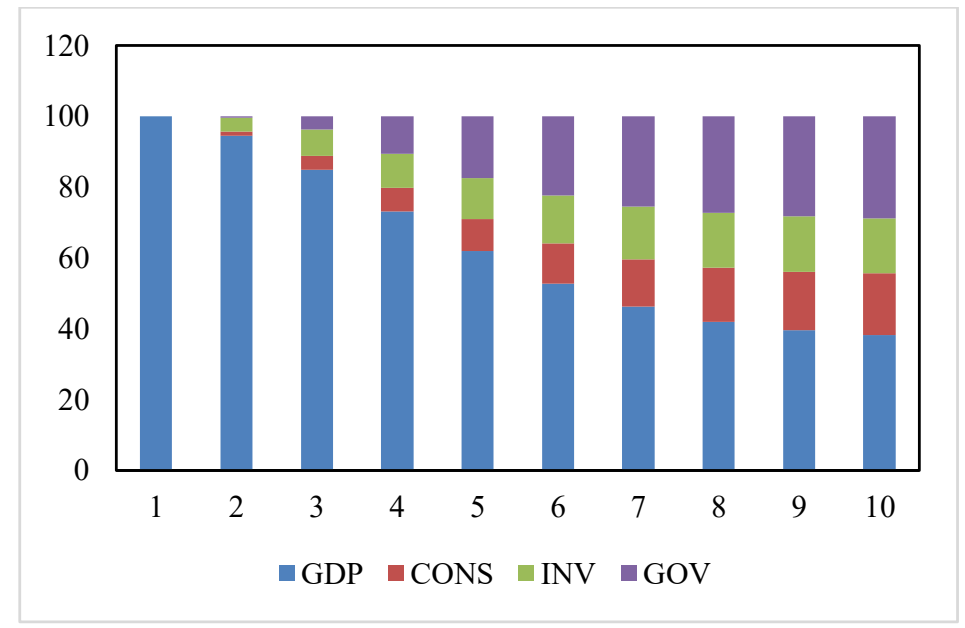

Figure 2. Variance Decomposition 
The results of this FEVD show the dynamic contribution of the variables studied to the diversity of GDP (economic growth). In the second year, the diversity of GDP was most affected by GDP itself, then CONS (tourism sector consumption), INV (tourism sector investment), and GOV (government spending in the tourism sector). Meanwhile, in the tenth year the contribution of GDP itself to the diversity of GDP has declined. This decline in the contribution of GDP was replaced by an increase in contributions from other variables, especially INV.

\section{CONCLUSION}

The main conclusion obtained from this study is that the increase in consumption, investment and government expenditure in the tourism sector has a positive effect on economic growth. The influence of the three tourism variables occurred in the long-term analysis. Meanwhile, in the short-run analysis the three tourism variables do not affect economic growth.

Shocks that occur in government spending are responded positively by economic growth. Meanwhile, the shock of consumption and investment is responded negatively by economic growth. The contribution of variables of consumption, investment, and government expenditure is increasingly large in explaining variants of economic growth over the period of time of analysis.

Therefore, to optimize the role of the tourism sector in supporting national economic growth, the central, regional and all relevant stakeholders need to formulate strategic measures that support the development of national tourism so as to increase the number of tourists visiting both domestic and foreign tourists, which in eventually it will increase the consumption of the tourism sector. Investment in the tourism sector through improving the quality of public services and other supporting facilities also needs to be improved so that tourists are more easily able to get information and accommodations to go to tourist attractions. Sustainability of government spending in the tourism sector also needs to be maintained to support the development of the national tourism sector so that it is more efficient and competitive.

\section{REFERENCES}

Arslanturk, Y., Balcilar, M, \&Ozdemir, ZA. (2010). Time-Varying Linkages Between Tourism Receipts and 
Economic Growth in a Small Open Economy. Economic Modelling, 28: 664-671.

Brida, GJ, Pereyra SJ, Riso AD, Devesa SJM, Aguirre SJ. 2008. The Tourismled Growth Hypothesis: Empirical Evidence from Colombia. Tourismos: An International Multidisciplinary Journal of Tourism 4(13-27).

Eugenio-Martin JL., Morales, NM.\& Scarpa, R. (2004). Tourism and Economic Growth in Latin American Countries: A Data panel Approach. ISSN: 2037- 1209. The Spanish Case. Applied Economics Journal, 34:877884.

Firdaus, M. (2011). Aplikasi Ekonometrika untuk Data Panel dan Time Series. Bogor (ID): IPB Press.

Hermawan, A. (2009). Penelitian Bisnis Paradigma Kuantitatif. Jakarta: PT Gramedia Widyasarana Indonesia.

Juanda, B., Junaidi. (2013). Ekonometrika Dere tWaktu: Teori dan Aplikasi. Bogor(ID): IPB Press.

[Kemenpar] Kementerian Pariwisata. (2012). Kinerja Statistik Kementerian Pariwisata dan Ekonomi Kreatif Republik Indonesia. Data [internet]. [Diakses pada 5 September 2016]. Tersedia pada http://www.kemenpar.go.id
Lumaksono, A., Priyarsono, D., Kuntjoro., \& Heriawan, R. (2012). Dampak Ekonomi Pariwisata Internasional pada Perekonomian Indonesia. Forum Pascasarjana. 35(1):53-68. Bogor (ID): IPB.

Nath, S. (1998). Environmental Resources, International Tourism and Taxation: The Case of Mauritius. Social Sciences \& Humanities and Law \& Management Research Journal, 1:83110.

Nuryadin, D., Sodik, J.(2005). Investasi dan Pertumbuhan Ekonomi Regional (StudiKasus Pada 26 Propinsi di Indonesia, Pra dan Pasca Otonomi). Jurnal Ekonomi Pembangunan UPN "Veteran" Yogyakarta, 10:157 - 170.

Prabowo, MA. (2009). Dampak Ekonomi Sektor Pariwisata Indonesia Tahun 2005: Analisa Model Input-Output. [Skripsi]. Jakarta: Universitas Indonesia.

Sinclair, T.,Stabler, M. (1997). The Economics of Tourism. London: Routledge.

Tambunan, T. (2001). Perekonomian Indonesia: Teori dan Temuan Empiris. Jakarta: Ghalia Indonesia

[World Tourism Organization] WTO. (2003). Tourism Highlights. World Tourism Organization. Madrid.

[World Tourism \& Travel Council] WTTC. (2014). Data. [Internet]. [Diaksespada 5 September 2016]. Tersedia pada: http://www.wttc.org/. 